\title{
Feeding ecology of the crab Munida subrugosa (Decapoda: Anomura: Galatheidae) in the Beagle Channel, Argentina
}

\author{
M. Carolina Romero* ${ }^{\ddagger}$, Gustavo A. Lovrich*, Federico Tapella* and Sven Thatje ${ }^{\dagger}$ \\ *Centro Austral de Investigaciones Científicas, CADIC. CG 92, V9410BFD, Ushuaia, Tierra del Fuego, Argentina. \\ ${ }^{\dagger}$ Alfred Wegener Institute for Polar and Marine Research (AWI), PO Box 120 161, D-27568 Bremerhaven, Germany. \\ ${ }^{\ddagger}$ Corresponding author, e-mail: carofrau@tierradelfuego.org.ar
}

\begin{abstract}
Munida subrugosa is the most abundant galatheid crab species in the Beagle Channel $\left(55^{\circ} \mathrm{S} 68^{\circ} \mathrm{W}\right)$ off Tierra del Fuego, Argentina. Samples of crabs and the epibenthic community were taken on a monthly basis at two different depth strata $(<40 \mathrm{~m}$ and $>70 \mathrm{~m}$ ), by means of epibenthic trawling from 1998 to 1999. Stomach contents from 1582 crabs were analysed, out of which only $2 \%$ had empty stomachs. The quantity of food in the stomach contents was clearly seasonal and similar at both depths. The organic matter varied throughout the year and between both depths, being significantly higher in summer/spring than in autumn/winter. Munida subrugosa shows two different and simultaneous feeding habits: (1) as a predator M. subrugosa feeds on crustaceans, algae, and polychaetes; and (2) as a deposit feeder M. subrugosa consumes particulate organic matter and organisms associated with the superficial layer of the sediment. The composition of the diet of Munida subrugosa was similar for both years, and independent of depth, sex or season. Munida subrugosa selected crustaceans only in autumn and winter, whereas most food items were found according to their availability in the habitat.
\end{abstract}

\section{INTRODUCTION}

Munida subrugosa (White, 1847), is an anomuran crab of $5-7 \mathrm{~cm}$ in total length and $\sim 15 \mathrm{~g}$ in wet weight. This crab occurs in high concentrations in southern South America (Rayner, 1935): from $35^{\circ} \mathrm{S}$ on the Atlantic and $41^{\circ} \mathrm{S}$ on the Pacific, to $55^{\circ} \mathrm{S}$. Near the Beagle Channel and in terms of biomass, $M$. subrugosa constitutes up to $50 \%$ of the benthic community (Arntz \& Gorny, 1996). In terms of abundance, $M$. subrugosa represents $>85 \%$ to the anomuran and brachyuran crab assemblages (Arntz \& Gorny, 1996).

Galatheid crabs are considered key species because of their abundance and trophic position (Romero, 2003, and references therein). For example, maximum densities are: Pleuroncodes monodon (H. Milne-Edwards, 1837) from south-eastern Pacific, 10,000 individuals. $100 \mathrm{~m}^{-2}$, $P$. planipes Stimpson, 1860 off the Mexican Pacific, 4000 individuals $\cdot 100 \mathrm{~m}^{-2}$, and Munida sarsi Huus, 1935 in the North Atlantic, $>2000$ individuals $\cdot 100 \mathrm{~m}^{-2}$. Reported densities of $M$. subrugosa for the coastal southern South America varied from 50 to 2700 individuals $100 \mathrm{~m}^{-2}$ (Romero, 2003). In the Beagle Channel, densities of M. subrugosa are maximum at $<40 \mathrm{~m}$ depth and reportedly 100 individuals $100 \mathrm{~m}^{-2}$, and an average biomass of $3.4 \mathrm{t} \cdot \mathrm{km}^{-2}$ (F. Tapella, unpublished data).

Galatheid crabs show a wide spectrum of feeding habits, from ingesting particulate organic matter to cannibalism, with several intermediate situations. On the Mediterranean slope, Munida tenuimana Sars, 1872 is detritivorous as an adaptation to the scarcity of resources typical of the deep environment $>1000 \mathrm{~m}$ depth (Cartés, 1993). In the south-eastern Pacific, Pleuroncodes monodon has been described as omnivorous, with vegetarian or carnivorous tendencies, depending on the availability of food (Madrid, Departamento de Oceanografía, Universidad de Concepción, Chile, personal communication). Off the Mexican Pacific coast and during the benthic phase, $P$. planipes feeds on particulate organic matter and diatoms, filtering particles as small as 30-80 $\mu \mathrm{m}$ (Aurioles Gamboa \& Pérez Flores, 1997). Off New Zealand Munida gregaria (Fabricius, 1793) is cannibalistic (Zeldis, 1985). Larval stages, juveniles and adults of galatheids are prey of several top predators, e.g. whales, sea-lions, dolphins, otters, fish, crustaceans, and sea-birds (Romero, 2003), most of which are commercial species.

The aim of this study is to describe the natural diet of Munida subrugosa from the subantarctic Beagle Channel. The feeding habits and preferences, seasonal, sexual and depth variation in the diet were documented. This information will be helpful to determine its trophic role in the subantarctic coastal ecosystem.

\section{MATERIALS AND METHODS}

Field sampling

Sampling was carried out in the Beagle Channel, which is situated in the southern tip of South America $\left(55^{\circ} \mathrm{S}\right.$ $\left.68^{\circ} \mathrm{W}\right)$. The water temperature and salinity present a well-defined seasonality, ranging between 5.4 and $9.8^{\circ} \mathrm{C}$ and 28 and 30 psu, respectively (Lovrich, 1999).

Sampling for crabs was done on a monthly basis in a sector of $45 \mathrm{~km}$ of the Beagle Channel, from Bahía Lapataia $\left(54^{\circ} 52^{\prime} \mathrm{S} 68^{\circ} 32^{\prime} \mathrm{W}\right)$ to Punta Segunda $\left(54^{\circ} 52^{\prime} \mathrm{S}\right.$ $\left.68^{\circ} 02^{\prime} \mathrm{W}\right)$, from March 1998 to December 1999. Samples were obtained with an epibenthic trawl of $10-\mathrm{mm}$ mesh size and $1.7 \mathrm{~m}$ mouth width. Three randomly selected positions in each of two depth strata $(<40 \mathrm{~m}$ and $>70 \mathrm{~m})$ were sampled on each occasion. There is a steep depth change from 40 to $70 \mathrm{~m}$, and hence intermediate 


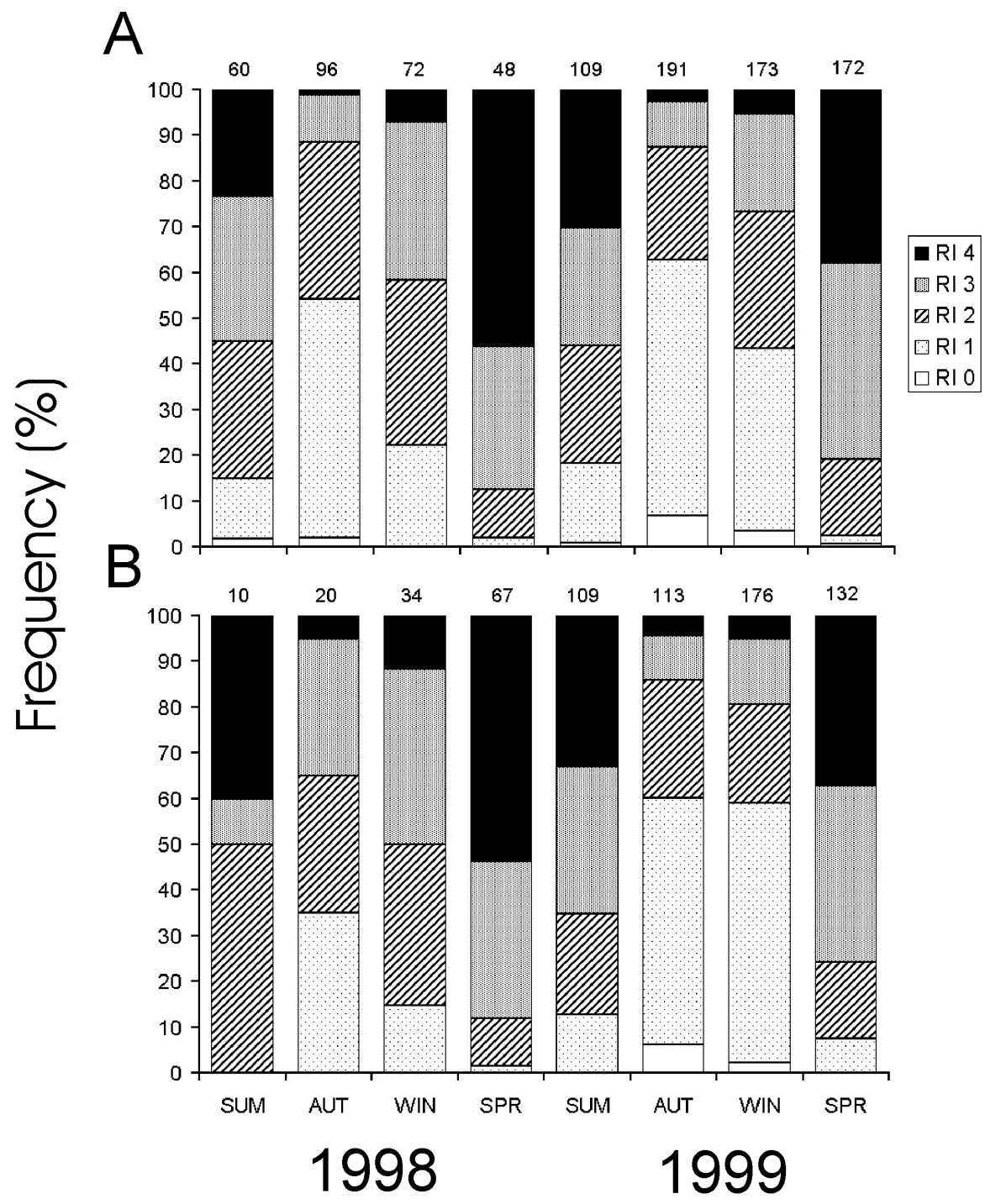

Figure 1. Repletion index of Munida subrugosa at $(\mathrm{A})<40 \mathrm{~m}$ and $(\mathrm{B})>70 \mathrm{~m}$ depth, in the Beagle Channel. SUM, summer; AUT, autumn; WIN, winter; SPR, spring. Numbers above bars are sample sizes.

sampling depths were not considered. All but 30 crabs were immediately fixed in $4 \%$ buffered formalin seawater. The other 30 crabs were frozen at $-18^{\circ} \mathrm{C}$. The standard measure of body size, carapace length (CL), was determined to the nearest $0.01 \mathrm{~mm}$ on all crabs by means of a dial calliper. Only crabs $>10 \mathrm{~mm}$ CL were used because they are gonadal mature and can be considered as adult individuals (Tapella et al., 2002).

\section{Analysis of the natural diet}

To identify food items and quantify their relative abundance and frequency of occurrence in the stomach contents, animals of the formalin sub-samples were used. Crabs were dissected and the stomach removed. Each stomach was weighed before and after extracting their contents. The difference in weight was considered as the weight of the stomach content (TW). Stomachs were characterized according to their repletion using an arbitrary scale, as follows: 0: empty; 1: $1-25 \% ; 2$ : $25-50 \% ; 3$ : $50-75 \% 4:>75 \%$. Stomach contents were transferred to Eppendorf tubes with $1 \mathrm{ml}$ of $4 \%$ formalin seawater, until their microscopic inspection.
Galatheids can be deposit feeders (Nicol, 1932) and therefore ingest a great quantity of sediment. Consequently, the repletion index (RI) may be an overestimation for food uptake. Hence, the amount of organic matter $(\mathrm{OM})$ in the stomach contents was used as a measure of food ingestion. To quantify the OM the frozen sub-samples from February to December of 1999 were used. Since the ash weight from one individual stomach content was low to the precision of our balance, five stomach contents were pooled. The stomach contents were dried to constant weight at $56^{\circ} \mathrm{C}$, weighed, burned for $24 \mathrm{~h}$ at $450^{\circ} \mathrm{C}$, and ashes weighed to the $0.1 \mathrm{mg}$. The $\mathrm{OM}$ was calculated as the difference between the dry and ash weights.

The quantity of ingested food depends on the animal size (Elner \& Lavoie, 1983), and therefore, TW and OM were standardized by CL. In the case of pooled stomach contents, the standardization was done on the basis of the average CL. A two-way analysis of variance (ANOVA) (Sokal \& Rohlf, 1995) was used to test both null hypotheses, of equal quantity of food and equal quantity of OM among seasons and depths. Assumptions of normality and homoscedasticity were previously tested with Kolmogorov-Smirnov and Bartlett's tests, respectively 


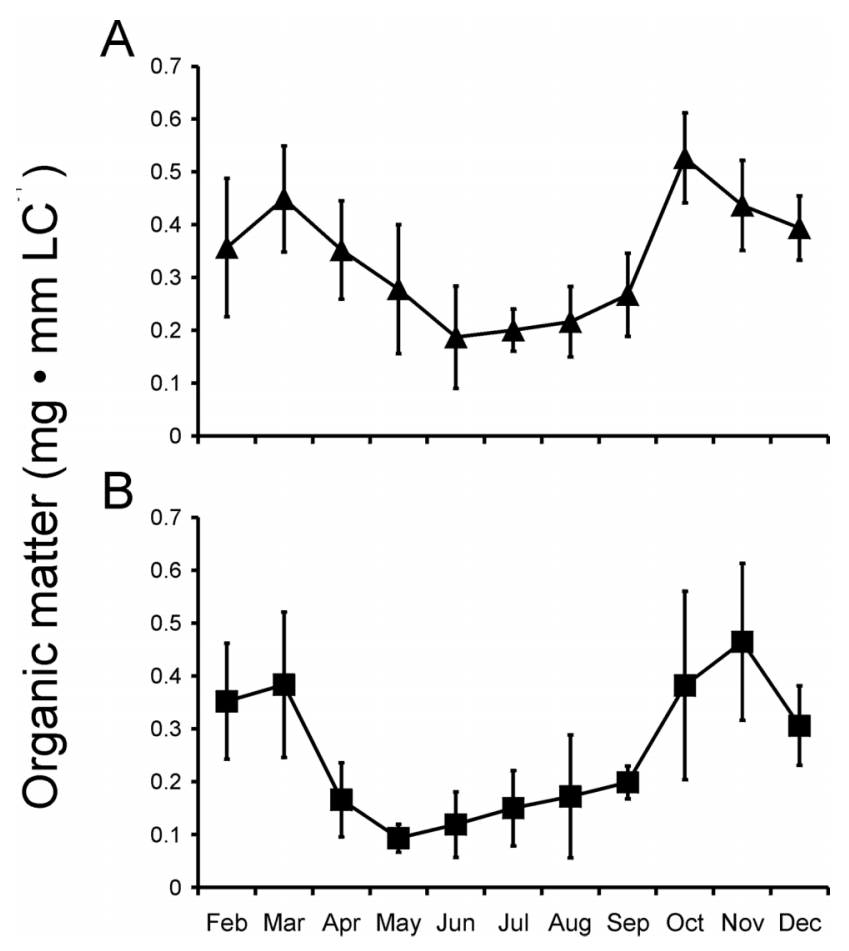

Figure 2. Monthly average $( \pm 1 \mathrm{SD})$ of organic matter in the stomach contents of Munida subrugosa at $<40 \mathrm{~m}$ (squares) and $>70 \mathrm{~m}$ (triangles) depth in the Beagle Channel.

(Sokal \& Rohlf, 1995). Statistical comparisons of the TW among seasons were done with Tukey-Kramer's T-method (Sokal \& Rohlf, 1995). Differences in the quantity of OM among different months were tested with planned contrasts (Sokal \& Rohlf, 1995).

\section{Identification and occurrence of prey}

Relatively large food items were identified to the lowest taxonomic level under a binocular microscope at $\times 20$ magnification. The importance of the different food components in the diet was estimated in two different ways. The relative abundance (RA) of each food item was calculated by re-adapting the technique reported by Kennish et al. (1996). Two $0.4 \mathrm{ml}$ sub-samples of the stomach content were mounted on slides and examined under a binocular microscope at $\times 100$ magnification. The occurrence of each item was recorded with an ocular grid marked with 25 intersection points. From each slide, three randomly selected fields were examined giving a total number of 150 intersection points for each animal. The RA was $i_{a} \cdot \sum_{i}^{-1} \cdot 100$, where $i_{a}$ is the number of intersection points for item a and $\sum_{i}$ is the number of intersection points for all items. The frequency of occurrence (FO) of each item was $\mathrm{N}_{\mathrm{i}} \cdot \mathrm{N}_{\mathrm{t}}^{-1} \cdot 100$, where $\mathrm{N}_{\mathrm{i}}$ is the number of stomachs with item $_{\mathrm{i}}$ and $\mathrm{N}_{\mathrm{t}}$ is the total number of stomachs.

Log-linear models (Sokal \& Rohlf, 1995) were used to analyse the variability in the number of stomachs containing the most common prey. The influence of different factors on the consumption of each prey was analysed by fitting log-linear models by the maximum likelihood method to contingency tables made up of the following variables: prey (presence-absence), depth stratum $(<40 \mathrm{~m}->70 \mathrm{~m})$, sex (female-male), season (summer-autumn-winter-spring).

\section{Food selectivity}

In order to evaluate the composition of potential preys of Munida subrugosa, during 1999 three samples of the epibenthic community were taken every three months in both depth strata. Samples were obtained with an epibenthic sledge of $0.4 \mathrm{~m}$ mouth width and $1-\mathrm{mm}$ of mesh size. In the laboratory, nets were washed on a $0.25-\mathrm{mm}$ sieve, and contents were fixed in $4 \%$ buffered formalin seawater, and preserved in ethanol:water 70:30. Samples were sorted and all organisms were classified to the lowest taxonomic level. Individuals of each taxa were weighed and their relative abundance was $\mathrm{RA}_{\mathrm{b}}=\mathrm{W}_{\mathrm{i}} \cdot \mathrm{W}_{\mathrm{t}}^{-1} \cdot 100$, where $\mathrm{W}_{\mathrm{i}}$ is the total weight of the benthic component ${ }_{i}$ and $\mathrm{W}_{\mathrm{t}}$ is the total weight of all benthic organisms in each sample.

Preferences in the diet of Munida subrugosa were evaluated with the Linear Food Selection Index (L) (Strauss, 1979). L was calculated as $L=r_{i}-p_{i}$ where $r_{i}$ is the RA of the prey item $_{\mathrm{i}}$ in the stomach, and $\mathrm{p}_{\mathrm{i}}$ is the RA of the same prey item in the benthic community. The expected value of the index is zero for random or neutral feeding. The significance of $\mathrm{L}$ was tested against a value of zero using a Student's $t$-test. The variance of $\mathrm{L}$ was $\mathrm{S}^{2}{ }_{(\mathrm{L})}=\mathrm{r}_{\mathrm{i}}\left(1-\mathrm{r}_{\mathrm{i}}\right) \cdot \mathrm{n}_{\mathrm{r}}^{-1}+\mathrm{p}_{\mathrm{i}}\left(1-\mathrm{p}_{\mathrm{i}}\right) \cdot \mathrm{n}_{\mathrm{p}}^{-1}$ where $n_{r}$ and $n_{p}$ are the number of stomachs analysed and the number of benthic samples, respectively.

\section{RESULTS}

A total of 1582 specimens of Munida subrugosa were dissected. Average CL was $21.31( \pm \mathrm{SD}$ : 3.9$) \mathrm{mm}$ and $17.00( \pm 3.65) \mathrm{mm}$ for animals at $<40 \mathrm{~m}$ and $>70 \mathrm{~m}$ depth, respectively. The taxonomic composition of the diet was evaluated in 355 individuals: 239 from $<40 \mathrm{~m}$ depth and 116 from $>70 \mathrm{~m}$ depth. The OM was analysed in 858 specimens: 408 and 450 at $<40 \mathrm{~m}$ and $>70 \mathrm{~m}$ depth, respectively. Macroscopically, the stomach contents were a greenish mass, with more or less consistency depending on the digestion condition and the stomach repletion, which consisted of very small remains of organisms and sediment.

\section{Repletion index (RI)}

The RI was analysed for 921 and 661 specimens at $<40 \mathrm{~m}$ and $>70 \mathrm{~m}$ depth, respectively. Out of all specimens dissected, 21 and 11 specimens were found with empty stomachs $(\mathrm{RI}=0)$ at $<40 \mathrm{~m}$ and $>70 \mathrm{~m}$, respectively. The RI reflected less feeding in autumn than in all other seasons, being $50 \%$ of the animals with $\mathrm{RI}=1$ (Figure 1). Contrastingly, the highest repletion index $(\mathrm{RI}=3-4)$ was found in spring and summer. The RI was a good estimate of the quantity of $\mathrm{OM}$ in the stomach contents, because RI and OM were positively correlated at both depths $\left(\mathrm{r}_{\mathrm{s}<40 \mathrm{~m}}=0.82 ; P<0.001 ;\right.$ and $\mathrm{r}_{\mathrm{s}>70 \mathrm{~m}}=0.89$; $P<0.001)$.

\section{Quantity of food}

The quantity of food in the stomach contents (TW) of M. subrugosa was clearly seasonal (ANOVA, $F=79.6$, 
Table 1. Frequency of occurrence ( $F O)$ and relative abundance (RA) of food items of Munida subrugosa at two depth strata in the Beagle Channel. POM, particulate organic matter.

\begin{tabular}{|c|c|c|c|c|c|}
\hline \multirow[b]{2}{*}{ Food items } & & \multicolumn{2}{|c|}{ Frequency of occurrence (FO) } & \multicolumn{2}{|c|}{ Relative abundance (RA) } \\
\hline & & $<40 \mathrm{~m}$ & $>70 \mathrm{~m}$ & $<40 \mathrm{~m}$ & $>70 \mathrm{~m}$ \\
\hline Sediment & & 97.1 & 100 & 22.6 & 31.4 \\
\hline POM & & 96.7 & 100 & 33.5 & 31.8 \\
\hline \multirow[t]{3}{*}{ Crustaceans } & Unidentified Crustacea & 46.4 & 64.7 & 10.7 & 14.9 \\
\hline & Munida spp. & 7.1 & 4.3 & 4.7 & 3.1 \\
\hline & Ostracoda & 1.7 & 6.9 & 0.1 & 1.3 \\
\hline Algae & Unidentified Algae & 35.2 & 31.0 & 5.1 & 2.9 \\
\hline \multirow[t]{5}{*}{ Chlorophyta } & Cladophora spp. & 10.9 & 7.8 & 0.7 & 0.6 \\
\hline & Rhizoclonium spp. & 3.8 & 0 & 0.2 & 0 \\
\hline & Chaetomorpha spp. & 1.3 & 0 & 0.1 & 0 \\
\hline & Ulva spp. & 0.8 & 0 & 0.1 & 0 \\
\hline & Monostroma spp. & 0 & 3.5 & 0 & 1.8 \\
\hline \multirow{5}{*}{ Phaeophyta } & Desmarestia spp. & 2.9 & 0.9 & 1.3 & 0.5 \\
\hline & Sphacelaria spp. & 1.3 & 4.3 & 0.1 & 0.2 \\
\hline & Halopteris spp. & 1.3 & 0 & 0.2 & 0 \\
\hline & Ectocarpus spp. & 0.4 & 0 & $<0.1$ & 0 \\
\hline & Hincksia spp. & 0 & 7.8 & 0 & 0.7 \\
\hline \multirow[t]{8}{*}{ Rhodophyta } & Trailliella spp. & 36.0 & 16.4 & 2.3 & 0.7 \\
\hline & Ballia spp. & 23.9 & 16.4 & 2 & 1 \\
\hline & Delesseriaceae & 3.4 & 3.5 & 1 & 2.1 \\
\hline & Bostrychia spp. & 1.3 & 0 & 0.1 & 0 \\
\hline & Hymenena spp. & 0.8 & 0.9 & 0.3 & 0.2 \\
\hline & Ceramium spp. & 0.4 & 2.6 & $<0.1$ & 0.1 \\
\hline & Griffithsia spp. & 0.4 & 1.7 & 0.2 & 0.5 \\
\hline & Myriogramme spp. & 0.4 & 0 & 0.1 & 0 \\
\hline \multirow{14}{*}{ Other } & Foraminifera & 65.3 & 32.8 & 2.7 & 1.1 \\
\hline & Bacillariophyta & 40.2 & 21.6 & 1.3 & 0.4 \\
\hline & Oligochaeta & 18.4 & 13.8 & 2.1 & 0.9 \\
\hline & Polychaeta & 18.4 & 9.5 & 5.5 & 1.6 \\
\hline & Nematoda & 15.1 & 30.2 & 0.7 & 1.4 \\
\hline & Bivalvia & 8.8 & 1.7 & 0.9 & 0.2 \\
\hline & Porifera & 5.9 & 1.7 & 0.1 & 0.1 \\
\hline & Hydrozoa & 5.4 & 2.6 & 0.1 & 0.1 \\
\hline & Vascular plants (Nothofagus spp?) & 4.6 & 0 & 0.9 & 0 \\
\hline & Echinoidea & 4.2 & 0 & 0.1 & 0 \\
\hline & Radiolaria & 1.3 & 19.0 & 0.1 & 0.5 \\
\hline & Bryozoa & 0.4 & 0 & 0.1 & 0 \\
\hline & Gastropoda & 0.4 & 0 & 0.1 & 0 \\
\hline & Cyanophyta & 0.4 & 0 & $<0.1$ & 0 \\
\hline
\end{tabular}

$P<0.001)$ and did not show differences between both depths (ANOVA, $F=1.2, P=0.28$ ). The mean standardized TW was $2.22 \pm 1.46 \mathrm{mg} \cdot \mathrm{mm} \mathrm{CL}^{-1}$, (range 0.11-9.05 $\mathrm{mg} \cdot \mathrm{mm} \mathrm{CL}{ }^{-1}$ in autumn and summer, respectively). Also, TW was not dependent on the interaction among depths and seasons (ANOVA, $F=1.8, P=0.15$ ). The TWs in autumn and winter were similar (Tukey test $P=0.99$ ), whereas the highest ingestion rate was registered in summer, and significantly different to that of the other three seasons (Tukey test $P<0.001$ ).

The quantity of $\mathrm{OM}$ in the stomach contents of $M$. subrugosa varied throughout the year (ANOVA, $F=17.5$, $P<0.001$ ) and between depths (ANOVA, $F=23.2$, $P<0.001)$. The $\mathrm{OM}$ was significantly higher in summerspring than in autumn-winter $\left(\mathrm{F}_{\text {planned comparison }}=146\right.$, $P<0.001)$. The maximum $\mathrm{OM}$ was registered in spring and summer, and it was 0.65 and $0.63 \mathrm{mg} \mathrm{OM} \cdot \mathrm{mm} \mathrm{CL}^{-1}$, at $<40 \mathrm{~m}$ and at $>70 \mathrm{~m}$, respectively. These values were ten-fold the minima OM that occurred in autumn: 0.06 and $0.05 \mathrm{mg} \mathrm{OM} \cdot \mathrm{mm} \mathrm{CL}{ }^{-1}$, at $<40 \mathrm{~m}$ and at $>70 \mathrm{~m}$ depth, respectively (Figure 2). The absence of statistical interaction between months and depths (ANOVA, $F=0.96, P=0.49)$ indicates that the feeding pattern was similar at both depths.

During February-December 1999, the percentage of OM in the stomach contents was constant: 49.7 ( \pm 13.9$) \%$ for specimens at $<40 \mathrm{~m}$ depth, and $51.9( \pm 13.7) \%$ for specimens at $>70 \mathrm{~m}$ depth. The percentage of $\mathrm{OM}$ at both depths were similar (Student's $t$-test, $t=-0.86$, $P=0.20)$.

\section{Natural diet}

The diet of Munida subrugosa from the Beagle Channel consisted of at least 30 food items (Table 1). According to their biological characteristics, food items can be sorted into two different categories: sediment and particulate organic matter (POM), and organic remains of 


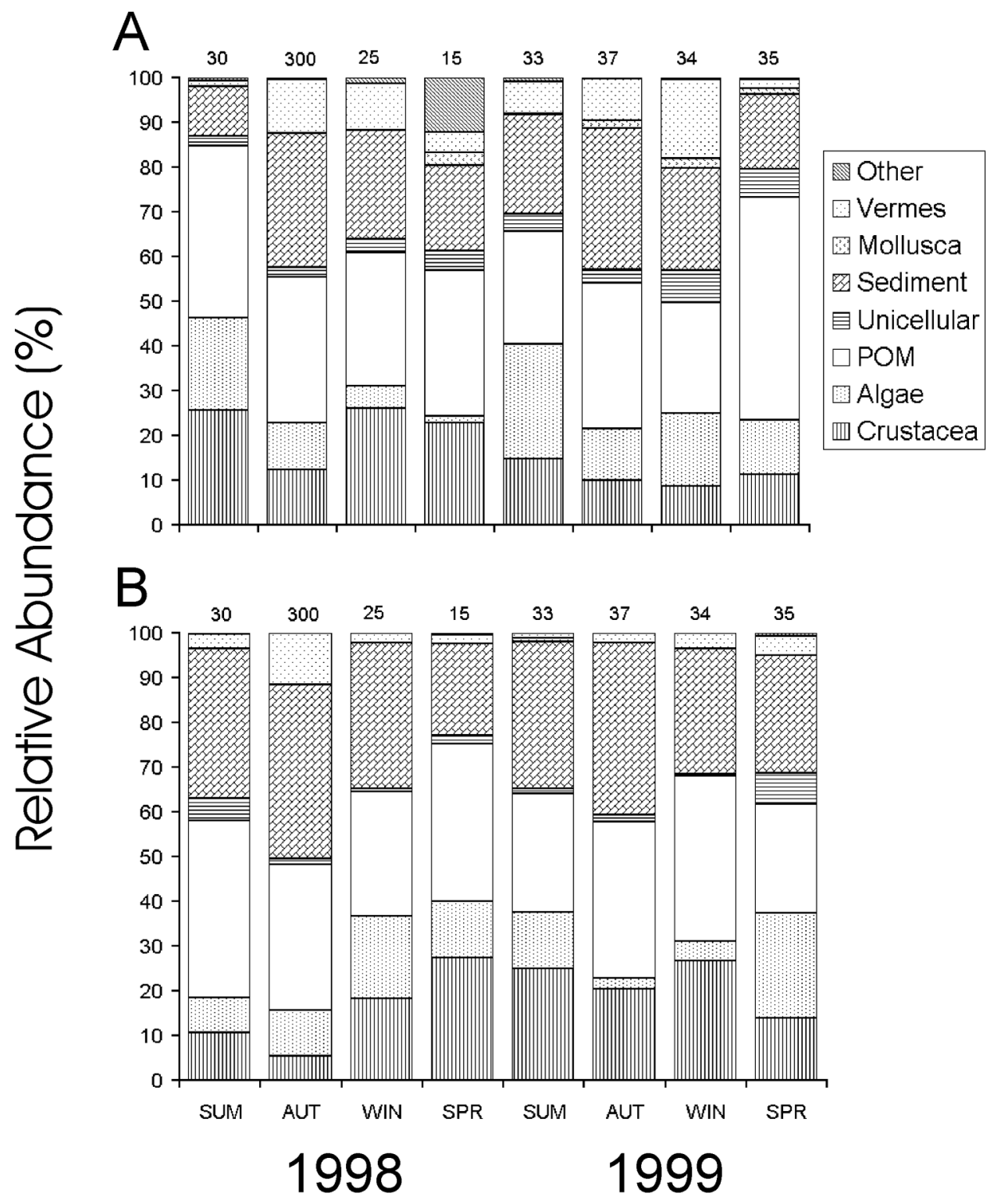

Figure 3. Relative abundance of the main food items of Munida subrugosa at $(\mathrm{A})<40 \mathrm{~m}$ and $(\mathrm{B})>70 \mathrm{~m}$ depth in the Beagle Channel. SUM, summer; AUT, autumn; WIN, winter; SPR, spring. Numbers above bars are sample sizes.

organisms. Sediment and POM were found virtually in all stomachs, with frequencies of occurrence (FO) $>95 \%$ (Table 1). In terms of RA, both items were the most abundant ones and together represented $56 \%$ and $63 \%$, at $<40 \mathrm{~m}$ and $>70 \mathrm{~m}$ depth, respectively (Table 1). Similarly, organisms associated with the upper layer of sediment, as for example foraminiferans, diatoms and radiolarians were among the most frequent food items. However, their RA were low. Some of the POM was identified as remains of vascular plants, which occurred only at $<40 \mathrm{~m}$ depth.

Munida subrugosa fed mainly on crustaceans, small macroalgae and polychaetes. In the stomach contents and in terms of FO, crustaceans, algae and vermes were the most important food items, occurring in at least 35\% of all stomachs (Table 1). The FO of crustaceans and polychaetes was consistent with their RA, indicating that these items are the main prey. The RA of algae in the stomach contents was low compared with their FO, probably due to their small size and the low probability of intersection with each of our sampling points. The specific algae composition of the diet showed some differences between depths (Table 1).

The diet composition of Munida subrugosa was similar in both years, and independent of depth, sex or season (Figure 3; Table 2). For each main component of the diet, the null hypothesis of equal frequency of occurrence among depths, seasons and sexes could not be statistically rejected (Table 2). Similarly, these main diet items did not show a clear seasonal pattern of occurrence (Figure 3). Nevertheless, at both depths the relative abundance of sediment was maximum in autumn, and the relative abundance of vermes peaked in autumn and winter. Algae were most abundant in the stomach contents during summer at $<40 \mathrm{~m}$ depth.

\section{Selectivity}

The selectivity index (L) showed that Munida subrugosa selected some food items, especially during autumn and 
Table 2. Probabilities of the analysis of consumption of main food items of Munida subrugosa using log-linear models fitted to contingency tables. Model design is prey (2) $\times$ depth (2) $\times$ sex $(2) \times$ season (4), contrasted with an $\alpha=0.05$. POM, particulate organic matter. Samples from 1998 and 1999 were pooled.

\begin{tabular}{|c|c|c|c|c|c|c|c|}
\hline Food items & Depth $\times$ season $\times$ sex & Depth $\times$ season & Depth $\times$ sex & Sex $\times$ season & Sex & Depth & Season \\
\hline Crustaceans & 0.70 & 0.48 & 0.75 & 0.88 & 0.92 & 0.49 & 0.63 \\
\hline Algae & 0.86 & 0.83 & 0.70 & 0.81 & 0.72 & 0.75 & 0.94 \\
\hline POM & 0.93 & 0.99 & 0.98 & 0.92 & 0.89 & 0.99 & 0.95 \\
\hline Sediment & 0.95 & 1.00 & 0.98 & 0.94 & 0.90 & 0.99 & 0.98 \\
\hline
\end{tabular}

Table 3. Strauss linear food selective index for Munida subrugosa at $<40 \mathrm{~m}$ and at $>70 \mathrm{~m}$ depth in the Beagle Channel, during 1999. Asterisks indicate that the index is significantly different from 0 at $\mathrm{P}<0.05$.

\begin{tabular}{|c|c|c|c|c|c|c|c|c|}
\hline & \multicolumn{2}{|c|}{ Summer } & \multicolumn{2}{|c|}{ Autumn } & \multicolumn{2}{|c|}{ Winter } & \multicolumn{2}{|c|}{ Spring } \\
\hline & $<40 \mathrm{~m}$ & $>70 \mathrm{~m}$ & $<40 \mathrm{~m}$ & $>70 \mathrm{~m}$ & $<40 \mathrm{~m}$ & $>70 \mathrm{~m}$ & $<40 \mathrm{~m}$ & $>70 \mathrm{~m}$ \\
\hline Crustacea & 0.15 & 0.34 & $0.29 *$ & $0.75^{*}$ & $0.17 *$ & $0.73 *$ & 0.26 & 0.25 \\
\hline Algae & 0.32 & -0.01 & 0.26 & $0.09 *$ & $-0.60 *$ & 0.13 & -0.25 & 0.43 \\
\hline Vermes & 0.11 & $<0.01$ & $-0.61^{*}$ & $0.07 *$ & $0.35 *$ & -0.06 & 0.05 & 0.08 \\
\hline Mollusca & -0.02 & -0.35 & 0.06 & $-0.93 *$ & 0.03 & -0.80 & -0.02 & -0.18 \\
\hline Foraminifera & 0.06 & 0.02 & 0.06 & $0.06^{*}$ & 0.09 & 0.01 & $0.14 *$ & 0.09 \\
\hline Hydrozoa & 0.01 & - & $\leqslant 0.01$ & - & - & - & - & - \\
\hline Porifera & -0.26 & - & $<0.01$ & -0.02 & -0.03 & - & -0.10 & 0.01 \\
\hline Brachyopoda & -0.08 & - & $\leqslant 0.01$ & - & $\leqslant 0.01$ & - & $\leqslant 0.01$ & -0.01 \\
\hline $\begin{array}{l}\text { Echinoder- } \\
\text { mata }\end{array}$ & -0.30 & -0.01 & -0.03 & - & $\leqslant 0.01$ & - & $<0.01$ & $\leqslant 0.01$ \\
\hline Bryozoa & - & - & $\leqslant 0.01$ & -0.02 & - & - & -0.08 & $-0.66^{*}$ \\
\hline
\end{tabular}

winter (Table 3). Crustaceans were selected in autumn and winter at both depths analysed. Algae were selected only in autumn at $>70 \mathrm{~m}$ depth, and were rejected in winter at $<40 \mathrm{~m}$ depth. Vermes were selected in autumn at $>70 \mathrm{~m}$ depth and in winter at $<40 \mathrm{~m}$ depth, respectively. As a general pattern, other food items (echinoderms, bryozoans, sponges, vascular plants) were consumed according to the availability in the habitat at both depths without a seasonal pattern of preference.

\section{DISCUSSION}

Feeding habits of Munida subrugosa

Munida subrugosa of the Beagle Channel shows two different and simultaneous feeding habits: as a predator and as a deposit feeder. Typically, galatheids feed by two methods: large food pieces are sized by the chelae and maxillipeds and passed to the mandibles, or the third maxillipeds and pereiopods are used to collect finely divided material from the substratum (Nicol, 1932; Garm \& Høeg, 2000). On the one hand, the high FO of crustaceans $(76 \%)$ and macroalgae $(86 \%)$ in the stomach contents demonstrate that $M$. subrugosa catches prey and forages over algae. On the other hand, the presence of sediment, POM, and biological material associated with the benthic substrate, such as foraminifera, diatoms and nematodes, shows the ability of $M$. subrugosa as a deposit feeder. Deposit feeding is here hypothesized somewhat continuous as an easily accessible source of energy, supported by the fact that stomachs of $M$. subrugosa were rarely empty: only $2 \%$ throughout our study.
High densities of Munida subrugosa probably influence the feeding habits. Densities as high as 27 individuals $\cdot \mathrm{m}^{-2}$ imply that the distance between neighbour individuals may be closer than the extent of the antenna (cf. figure 4a in Gutt et al., 1999). Therefore the decision between chasing-hunting and deposit feeding is probably determined by agonistic behaviour (Zeldis, 1985). Animals held in communal tanks keep equidistant, minimizing their interactions (personal observation). Therefore, at high conspecific densities the best strategy, i.e. with less energy consuming and less individual interaction, is probably the deposit feeding.

Munida subrugosa from the Beagle Channel is omnivorous, because they prey on algae, invertebrates and POM. Munida subrugosa can also be considered as a generalist, since they consume food items according to their availability. The only exception is that $M$. subrugosa selects crustaceans during autumn and winter. Other items, such as molluscs and bryozoans, are avoided, which is probably due to the incapability of crabs to manage bivalves.

\section{Munida subrugosa shortens trophic chains}

Munida subrugosa is the direct trophic link between the detritus and the top predators of the Beagle Channel ecosystem. The remains of dead organisms - of both animal and vegetal origin - and the decomposer microorganisms associated with them, give the detritus a high nutritional value. The sediment could also act as a substrate to adsorb the dissolved organic matter in the environment. With its ability to feed and digest POM (Romero, 2003), M. subrugosa transforms POM into live 
tissues and makes it available to predators. Therefore trophic chains that include $M$. subrugosa are short and may be more efficient, in an efficient energetic transfer.

\section{Seasonal food uptake}

The food uptake in Munida subrugosa was clearly seasonal, reflected by the seasonal variation in the RI and TW, and the monthly variation of quantity of ingested OM. Crabs ingest more food between October and March (austral spring and summer) than during the rest of the year. This can be attributed to the fact that main physiological energetic requirements occur during spring and summer. Crabs moult during October (F. Tapella unpublished data), and yolk accumulation in oocytes occurs between February and May (Tapella et al., 2002). Therefore the energetic requirements in both processes probably need enhanced food uptake and explain this seasonal variation. By contrast, we did not find a clear seasonal pattern in the composition of the diet.

In the Beagle Channel, 16 of 18 genuses of algae fed by M. subrugosa are annual. Their biomasses, and therefore their availability, decrease during winter (Mendoza \& Nizovoy, 2000). Furthermore, maximum algal consumption was verified during each summer at $<40 \mathrm{~m}$ depth (Figure 3). Hence, a shift in the feeding mode of M. subrugosa, i.e. from algal foraging and/or predation to deposit feeding, could be expected to occur seasonally or associated with depth. The proportion of inorganic matter found in the stomach contents can be used as an indicator of the amount of ingested sediment as a deposit feeder (Pinn et al., 1998). Since the proportion of inorganic matter in the stomachs did not vary throughout the year or between depths, there is not such a change in the feeding habits. By contrast, crustaceans were actively selected during autumn and winter. Hence, we propose that both feeding habits are complementary. Decreasing availability of one prey component is replaced by capturing another live item, rather than switching the feeding habit.

We are grateful to A. Chizzini, M. Gutiérrez, A. Ferlito and C. Boy for field and laboratory assistance, and to M.L. Mendoza and A. Borasso for training in algae identification. We would like to thank J.A. Calcagno for statistical help. This project was financed by grants from CONICET (Consejo Nacional de Investigaciones Científicas y Técnicas) and Fundación Antorchas. Carolina Romero and F. Tapella have a research fellowship for graduates from CONICET. This research was partially financed by the AWI, Germany.

\section{REFERENCES}

Aurioles Gamboa, D. \& Pérez Flores, R., 1997. Seasonal and bathymetric changes in feeding habits of the red crab Pleuroncodes planipes (Decapoda, Anomura, Galatheidae) off the Pacific coast of Baja California Sur, Mexico. Crustaceana, 70, 272-287.
Arntz, W.E. \& Gorny, M., ed., 1996. Cruise report of the Joint Chilean-German-Italian Magellan 'Victor Hensen' Campaign in 1994. Berichte zur Polarforschung, 190, 1-113.

Cartés, J.E., 1993. Diets of two deep-sea decapods: Nematocarcinus exilis (Caridea: Nematocarcinidae) on the western Mediterranean slope. Ophelia, 37, 213-229.

Elner, R.W. \& Lavoie, R.E., 1983. Predation on American oysters (Crassostrea virginica (Gmelin)) by American lobsters (Homarus americanus Milne-Edwards), rock crabs (Cancer irroratus Say), and mud crabs (Neopanope sayi (Smith)). Fournal of Shellfish Research, 3, 129-134.

Garm, A. \& Høeg, J.T., 2000. Functional mouthpart morphology of the squat lobster Munida sarsi, with comparison to other anomurans. Marine Biology, 137, 123-138.

Gutt, J., Helsen, E., Arntz, W.E. \& Buschmann, A., 1999. Biodiversity and community structure of the mega-epibenthos in the Magellan region (South America). In MagellanAntarctic: ecosystems that drifted apart (ed. W.E. Arntz and C. Ríos). Scientia Marina, 63, Supplement 1, 155-170.

Kennish, R., Williams, G.A. \& Lee, S.Y., 1996. Algal seasonality on an exposed rocky shore in Hong Kong and the dietary implications for the herbivorous crab Grapsus albolineatus. Marine Biology, 125, 55-64.

Lovrich, G.A., 1999. Seasonality of larvae of Brachyura and Anomura (Crustacea: Decapoda) in the Beagle Channel, Argentina. In Magellan-Antarctic: ecosystems that drifted apart (ed. W.E. Arntz and C. Ríos). Scientia Marina, 63, Supplement 1, 355-360.

Mendoza, M.L. \& Nizovoy, A., 2000. Géneros de Macroalgas Marinas de la Argentina, fundamentalmente de Tierra del Fuego. Centro Austral de Investigaciones Científicas, Occasional Publication, $142 \mathrm{pp}$.

Nicol, E.A.T., 1932. The feeding habits of the Galatheidea. Fournal of the Marine Biological Association of the United Kingdom, 18, 87-106.

Pinn, E.H., James, R., Atkinson, R.J. \& Rogerson, A., 1998. Particle size selectivity and resource partitioning in five species of Thalassinidea (Crustacea: Decapoda). Marine Ecology Progress Series, 169, 243-250.

Rayner, G.W., 1935. The Falkland species of the crustacean genus Munida. Discovery Reports, 10, 212-245.

Romero, M.C., 2003. Hábitos alimentarios y bioenergética de la langostilla Munida subrugosa (Crustacea, Decapada) del Canal Beagle, Tierra del Fuego, Argentina. PhD thesis, Universidad Nacional de Córdoba, Argentina.

Sokal, R.R. \& Rohlf, F.J., 1995. Biometry: the principles and practice of statistics in biological research, 3rd edn. New York: Freeman \& Company.

Strauss, R.E., 1979. Reliability estimates for Ivlev's electivity index, the forage ratio, and a proposed Linear Index of Food Selection. Transactions of the American Fisheries Society, 180, 344-352.

Tapella, F., Lovrich, G.A., Romero, M.C. \& Thatje, S., 2002. Reproductive biology of the crab Munida subrugosa (Decapada: Anomura: Galatheidae) in the Beagle Channel, Argentina. Fournal of the Marine Biological Association of the United Kingdom, 82, 589-595.

Zeldis, J.R., 1985. Ecology of Munida gregaria (Decapoda, Anomura): distribution and abundance, population dynamics and fisheries. Marine Ecology Progress Series, 22, 77-99.

Submitted 12 December 2002. Accepted 13 January 2004. 